\title{
Surgery for exophthalmic goitre in Australia, 1907
}

by Selwyn Taylor

\section{SUMMARY}

Thomas Dunhill 1876-1957, Australian born surgeon (Melbourne 1907-1914. and London 1920-1941) performed partial thyroidectomy for exophthalmic goitre using Th.Kocher's method of local anaesthesia on seven consecutive severely toxic patients in 1907 with a successfull outcome in all seven. A brief outline of the life and achievements of Thomas Dunhill is appended.

In the year 1907 Thomas Dunhill, a surgeon at St. Vincent's Hospital in Melbourne, Australia, reported seven consecutive partial thyroidectomies for severe exophthalmic goitre, all the operations performed under local anaesthesia. All the patients survived though some required further operations, but the amazing thing is that seven patients with gross hyperthyroidism should have survived at all without any specific preparation of the overactive gland of any kind. All of these patients showed dramatic improvement and Dunhill attributed his success to the use of local anaesthetic for the operation as advocated by Professor Kocher in a paper in the British Medical Journal published in the previous year, 1906. All of the patients had severe heart damage and Dunhill pointed out that the uneventful recoveries that he had obtained were due to his using local infiltration instead of general anaesthesia with chloroform, which had proved extremely dangerous and given the operation a bad name.

Thomas Peel Dunhill, to give him his full name, was indeed a remarkable surgeon; born at Tragowel in the State of Victoria, Australia, on December 3rd, 1876, he lived until just after his 81st birthday and died in London in 1957. He began his career with no particular advantages and spent several years after leaving school working as an assistant in a chemist's shop so as to pay for his medical education. He then entered Melbourne University, graduated in pharmacy and went on to take first class honours in anatomy, physiology, medicine and gynaecology, qualifying at the age of 27 in 1903. He then worked for two years with William Moore and Sir Henry Maudsley at the Royal Melbourne Hospital and after another two years was appointed 


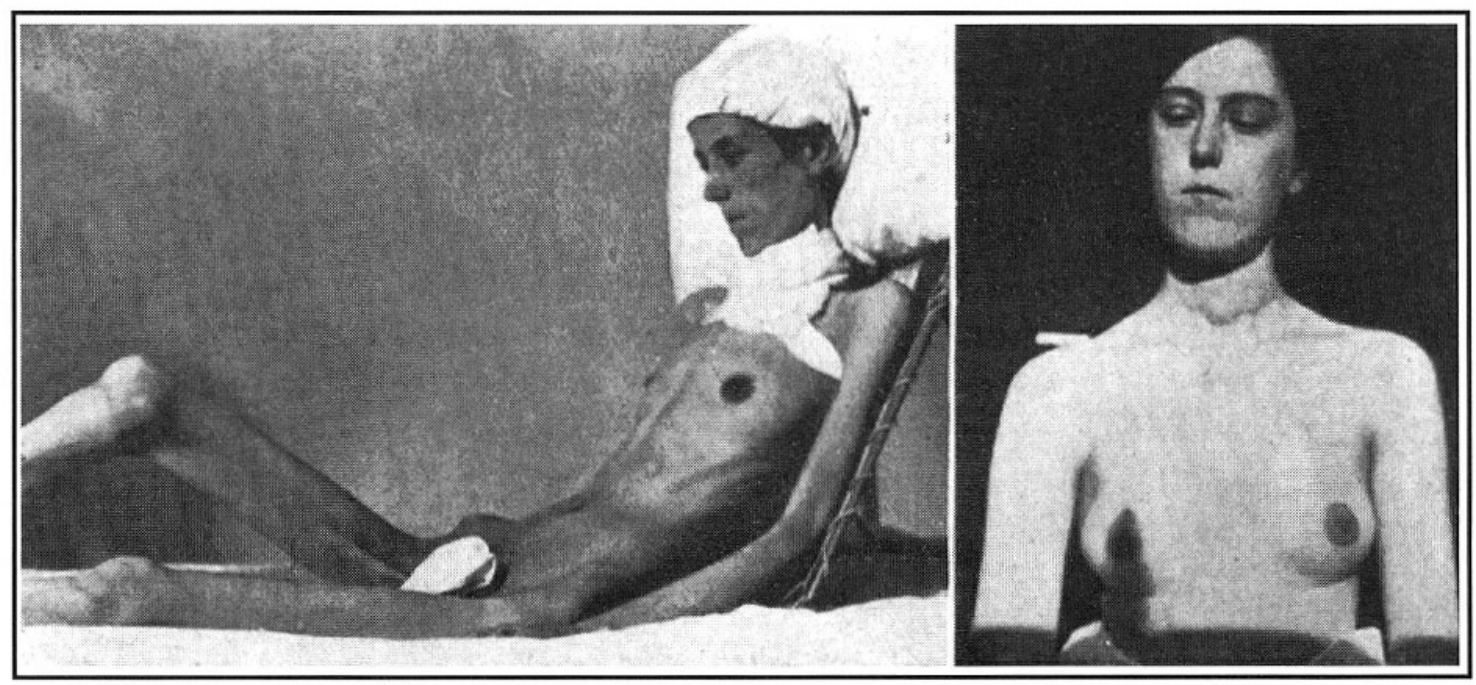

Fig.1: Dunhill's first patient with severe untreated exophthalmic goitre. A. before operation. B. some months after operation.

to the staff of St. Vincent's Hospital, Melbourne. By 1907, therefore, he was in a position to start in private practice as a surgeon in Collins Street. Dunhill seems even at this early age to have been attracted to the thyroid, and already as a house surgeon he had interested himself in the thyroid gland and had practised his surgical techniques by performing the operation of thyroidectomy on goats - partly in order that he might treat patients suffering from exophthalmic goitre with the milk of thyroidectomised animals; this was fashionable about 1900 . This operating was to stand him in good stead.

Dunhill continued to operate with success on patients with all types of goitre including some with toxic symptoms, until the Great War broke out in 1914 and he volunteered for service with the Australian Army Medical Corps and came to Europe. While serving with the army in France he contributed a further article on the surgery of exophthalmic goitre to the Lancet, which they published in 1917. In it he reported his concurrence

"with the views of Kocher, the Mayos and Crile that the disease can be practically cured by the removal of sufficient thyroid tissue when there has not been visceral degeneration and can be greatly ameliorated in most cases even when this has occurred".

The term "visceral degeneration" was the euphemism which Dunhill used to describe atrial fibrillation, heart failure and general emaciation. He had by that time performed operations on the thyroid gland about 1500 times and 
proceeded to give an excellent account of his experiences. As he was by then writing from a military hospital, "somewhere in France", he had no access to his records, but he provides a remarkable distillation of his eleven years of practice in Melbourne.

At this point I should record that Dunhill was a most gifted and delicate handler of the tissues with a meticulous operative technique. All of this was noted by his British colleagues in the army, and it was probably as a result of this that he was appointed to the staff of St. Bartholomew's Hospital in London soon after the end of hostilities. Dunhill subsequently had a brilliant career and was the doyen of surgeons in his own particular field of thyroid, parathyroid and oesophageal surgery. He was knighted when he served as Household Surgeon to King George the Fifth and, in 1939, George the Sixth made him Sergeant Surgeon. It was after attending the latter monarch's funeral that he contracted pneumonia and died although he was already debilitated by haemachromatosis, which had for long eluded diagnosis.

I was fortunate to know Dunhill in his later years having made his acquaintance at meetings of the London Thyroid Club. After his death I was asked to put his clinical papers in order and so have had the opportunity to study some of the very complete records which he kept and which are now stored at the Royal College of Surgeons in London. They include reports on

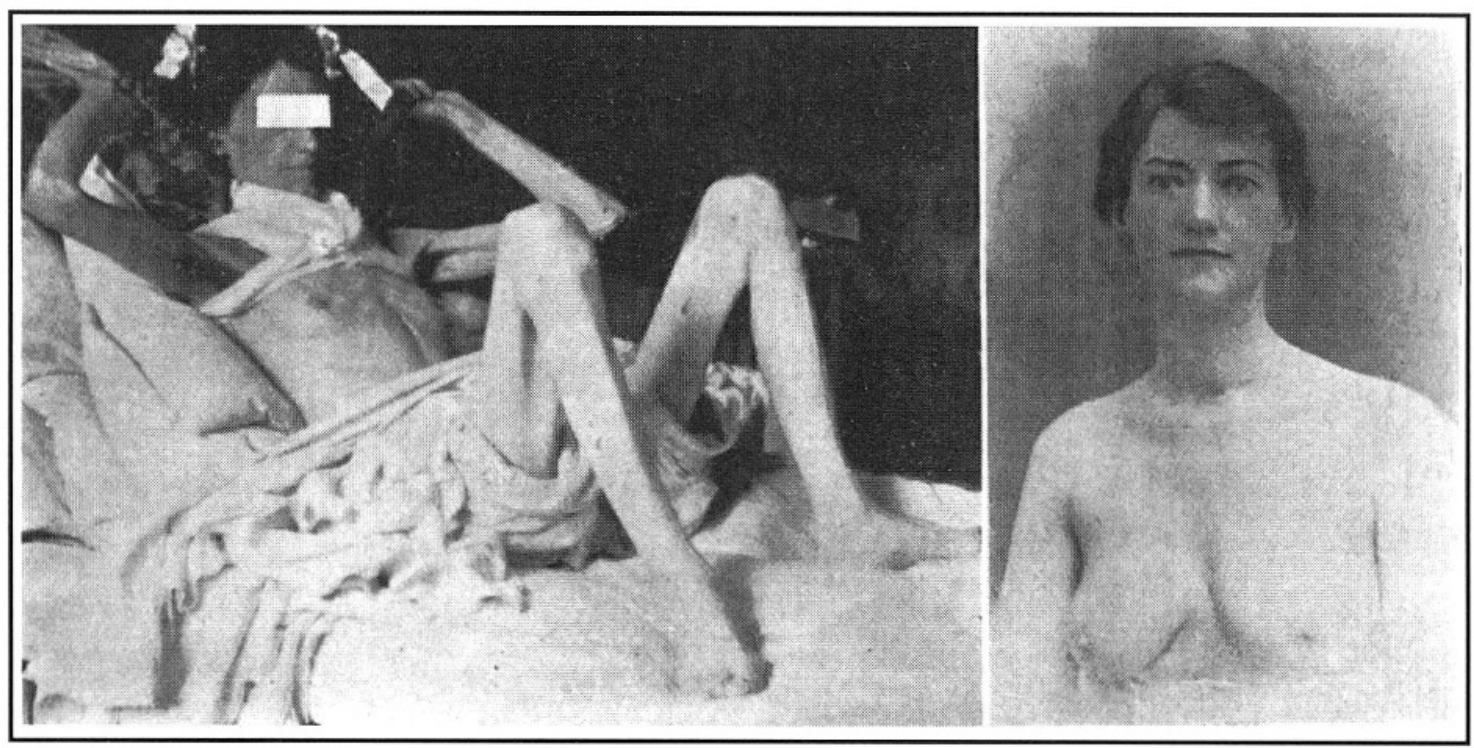

Fig. 2: Woman with gross wasting and cardiac involvement.

A. 10 days post-operative. B. 90 days after operation. 


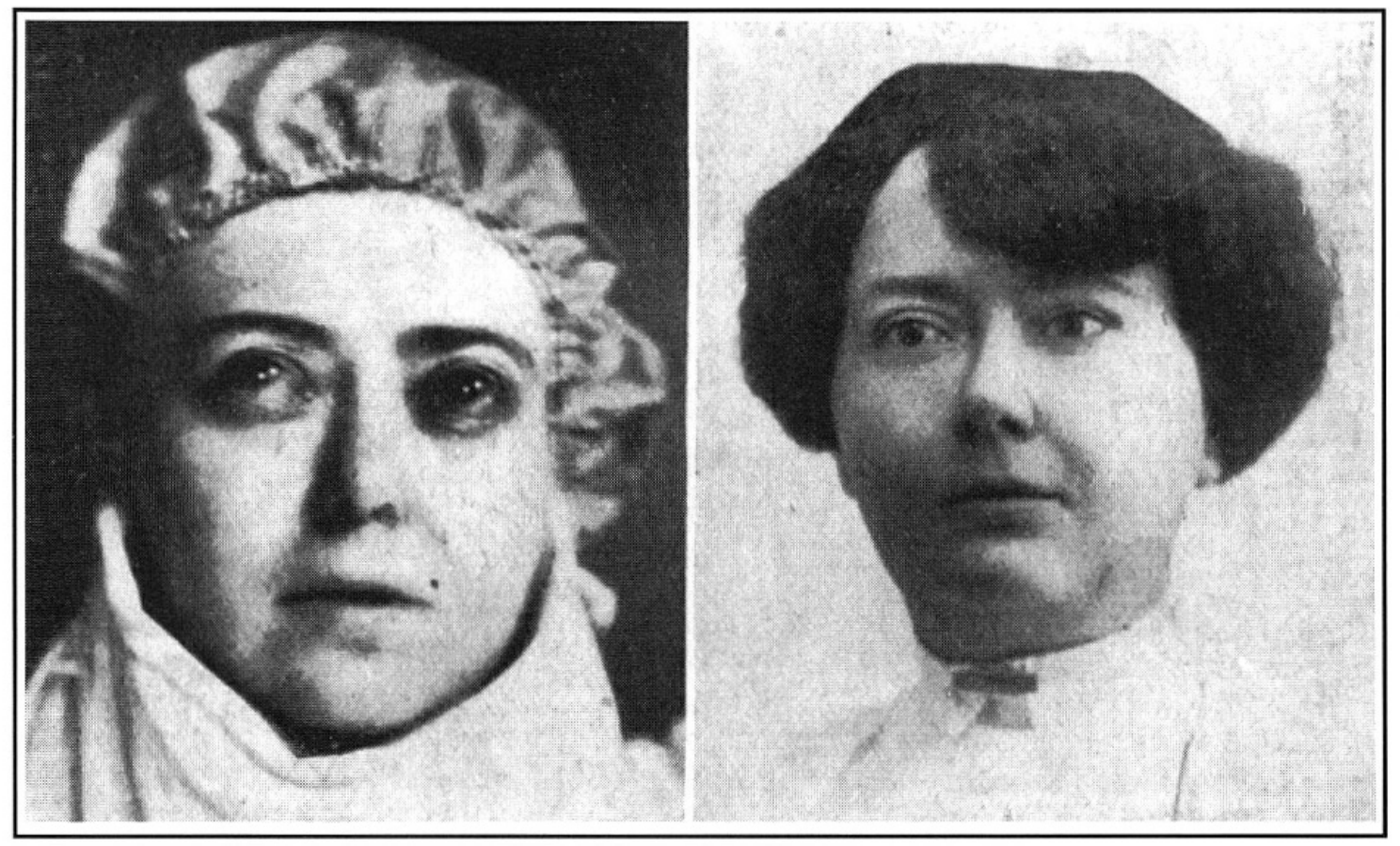

Fig. 3: Resolution of exophthalmos following thyroidectomy for Basedow's disease.

some 17000 thyroidectomies, all with histological slides and excellent follow-up notes.

Dunhill stated in his article that it was Kocher's earlier papers about operating under local anaesthetic which, with lightness of handling and rapidity of operation, gave him the stimulus to operate on these very toxic patients, and he described how he first went about it.

It was in 1906, when he first joined the hospital staff in Melbourne, that he found under his care

"five or six patients with exophthalmic goitre who were not making progress with the medical treatment available at that time".

They were the cast-offs of the medical department and when they were in desperate straits, emaciated, fibrillating and unlikely to survive, they were transferred to a surgical ward, naturally under the care of the youngest member of the staff, and Dunhill, who had only just been appointed, looked on the problem as a personal challenge. He recalled how he spent agonising hours walking up and down Collins Street discussing the problem with a colleague before he decided that he should offer operative treatment and 
attempt to excise as much of the overactive gland as he reasonably could. One woman of 36 , a cook, was so severely ill that she was shortly going to die, and so she was the first patient to be offered thyroidectomy, which she willingly accepted. Dunhill only removed the right lobe at the first operation, but there was immediate and striking improvement. Anatomically the right lobe is always larger than the left and, with the hyperplasia seen in this disease, disproportionately so.

I have appended here photographs of that original patient before operation and also post-operatively; the photographs which are now almost ninety years old, demonstrate the changes very well. As Dunhill writes:

"She so rapidly lost all the worst of her subjective symptoms and suffered so little discomfort from the operation itself that the other patients who had been associated with her in the out-patient room, on seeing her after the operation, one by one wished to be operated upon also. They all underwent operation and all without general anaesthesia, none of them died. Whatever may be my views now, there was no doubt in my mind then, nor was there in the minds of the physicians who saw these cases, that the infiltration with local anaesthetic was the chief factor in making for the safety of the operation".

Dunhill's article then stresses the importance of removing sufficient thyroid tissue and how he subsequently subjected some of his early patients to two and even three operations before their condition returned to normal. He gives detailed case histories to illustrate this, and the accompanying photographs show examples of a severity of emaciation due to Graves' disease seldom if ever encountered in these days.

As a personal remark I would add that Dunhill's surgical technique of extreme delicacy in handling the tissues and meticulous attention to detail must have been a significant factor in his remarkable success.

\section{References}

Dunhill, T. P., Exophthalmic Goitre: Partial Thyroidectomy under Local Anaesthesia. Intercolonial Medical Journal of Australasia 12 (1907), 589.

Dunhill, T. P., A Discussion on the Surgery of Exophthalmic Goitre. Lancet, 1917/2, 883.

Keynes, Sir G., Sir Thomas Dunhill, The first Dunhill Memorial Lecture delivered at the International Goitre Conference in London on 6th July 1960, Annals of the Royal College of Surgeons 29 (1961), 160-169.

Robinson, R. H. O. B., and LeFanu, W. R., Lives of the Fellows of the Royal College of Surgeons of England, London (Livingstone) 1970. 


\section{Zusammenfassung}

\section{Basedow-Chirurgie in Australien 1907}

Der zuerst in Melbourne, später in London tätige australische Chirurg thomas Dunhill (18761957) operierte 1907, am Anfang seiner beruflichen Laufbahn, sieben Basedow-Patienten mit schweren toxischen Symptomen. Nach Kochers Empfehlung führte er die partielle Thyreoidektomie in Lokalanästhesie aus. Alle sieben genasen. Dunhill schrieb diesen Erfolg dem Verzicht auf eine Allgemeinnarkose zu, aber seine sorgfältige, gewebeschonende Operationstechnik dürfte ebenfalls wesentlich dazu beigetragen haben.

\section{Résumé}

\section{Chirurgie de l'hyperthyrö̈dose en Australie en 1907}

Le chirurgien australien Thomas Dunhill (1876-1957), qui travaillait d'abord à Melbourne et plus tard à Londres, opéra avec succès, tout au début de sa carrière, sept malades qui souffraient d'hyperthyroïdose et qui présentaient tous de sévères symptômes toxiques. Il performa la thyroïdectomie partielle sous anesthésie locale - procédé recommandé par Kocher - et il attribua le succès de ses interventions au fait d'avoir évité la narcose, mais sa technique opératoire très subtile y contribua certainement aussi.

Selwyn Taylor

Trippets

GB-Bosham, Chichester

W. Sussex P018 8JE

(Dean Emeritus, Royal Postgraduate Medical School, Hammersmith Hospital, London, U. K.) 